\title{
The Measurement of Organizational Social Media Integration Impact on Financial and Innovative Performance: An Integrated Model
}

\author{
Ieva Meidute-Kavaliauskiene ${ }^{1, *}$, , Vida Davidaviciene ${ }^{1} \mathbb{C}$, Gencay Karakaya ${ }^{2}$ and Shahryar Ghorbani ${ }^{3}$ \\ 1 Department of Business Technologies and Entrepreneurship, Vilnius Gediminas Technical University, \\ Sauletekio Al. 11, 10223 Vilnius, Lithuania; vida.davidaviciene@vilniustech.lt \\ 2 Faculty of Business, Istanbul Commerce University, Istanbul 34445, Turkey; gkarakaya@ticaret.edu.tr \\ 3 Department of Production Management, University of Sakarya, Sakarya 54050, Turkey; \\ mg.shahryar@gmail.com \\ * Correspondence: ieva.meidute-kavaliauskiene@vilniustech.lt
}

check for

updates

Citation: Meidute-Kavaliauskiene, I.; Davidaviciene, V.; Karakaya, G.; Ghorbani, S. The Measurement of Organizational Social Media Integration Impact on Financial and Innovative Performance: An Integrated Model. Sustainability 2021, 13, 10397. https://doi.org/10.3390/ su131810397

Academic Editor: Jose Ramon Saura

Received: 18 August 2021

Accepted: 16 September 2021

Published: 17 September 2021

Publisher's Note: MDPI stays neutral with regard to jurisdictional claims in published maps and institutional affiliations.

Copyright: (c) 2021 by the authors. Licensee MDPI, Basel, Switzerland. This article is an open access article distributed under the terms and conditions of the Creative Commons Attribution (CC BY) license (https:/ / creativecommons.org/licenses/by/ $4.0 /)$.

\begin{abstract}
Organizations are investing in social media for communicating with customers, promoting employee collaborations, and integrating with partners and suppliers. One of the essential organizational capabilities that can help organizations create and share knowledge and improve their performance and create competitive advantage is social capital and social media integration. Therefore, while examining the role of social media integration on the three dimensions of social capital and the organizational emphasis on knowledge management, the present study has evaluated the impact of knowledge quality on improving organizational financial and innovative performance. This study was conducted in a sample of 280 employees of a bank in Iran. The present study had an applied data collection methodology, using structural equations modeling for analyzing with a descriptive correlational research goal. The results showed that integrated social media positively affects the social capital dimensions and organizational knowledge quality. This study highlights both the potential and limitations of social media in promoting organizational knowledge management. Businesses must consciously manage the assimilation and use of social media to benefit from them. The authors position the study at the intersection of social media, social capital, and knowledge management and explicate how social media works through social capital and organizational knowledge management efforts to affect knowledge quality.
\end{abstract}

Keywords: social capital; organizational social media integration; organizational knowledge quality; innovative performance

\section{Introduction}

In the information era, service organizations operate in a highly competitive and dynamic environment, in which the continuity and competitive advantage of organizations in such conditions depends on having knowledgeable, creative, and innovative employees. The existing knowledge in the organization provides a suitable platform for innovations and subsequent competitive advantages, and in return, organizational innovations enrich and increase the updating of organizational knowledge [1]. This is possible by implementing the principles of knowledge management in the organization. Organizations use social media to connect with their customers, promote employees, coordinate with partners and suppliers, and share knowledge [2]. Although organizations are increasingly sharing knowledge using social media, little research has been done on the relationship between social media integration and increasing organizational knowledge. In the present study, the authors tried to minimize this gap by examining the impact of social media integration on the quality of organizational knowledge management and, subsequently, on organizational performance. For this purpose, researchers used the framework of social capital from Tsai and Goshal (1998) as a theoretical basis in this study [3]. Experts see knowledge as the basic alternative to production, wealth, and monetary capital [4]. Knowledge is the 
only resource in the organization that, as a result of its use, has its value increased rather than reduced [5]. This knowledge is embedded in organizational procedures, guidelines, perspectives, actions, and decisions. A review of previous research showed that knowledge sharing can often minimize the production costs, hasten the completion of projects and new product development, increase integration, and maximize group performance and innovative capabilities [6].

Today's organizations are trying to improve their position among competitors and leaders. In that case, they should pay more attention to social media, social capital, and organizational knowledge management, which all create the quality of organizational knowledge and improve organizational performance, to take the obstacles in this area more seriously [7]. In the age of information explosion, traditional public relations no longer meet the needs of the organizations' customers. Today, modern media, especially social networks, cyberspace, mobile phones, and the Internet, are necessary in communication [8]. Today, about $70 \%$ of organizations use social technologies, such as blogs, Facebook, LinkedIn, etc., to increase their organizational knowledge and expertise [2]. Therefore, in a situation where organizations are increasing customers and their owners' expectations, knowledge management is essential due to its vital role in increasing the quality of organizational knowledge, promoting its innovative and financial performance, and gaining a competitive advantage $[9,10]$. Therefore, this study tried to investigate the impact of social media on social capital and organizational knowledge management and, subsequently, to examine their impact on knowledge quality at organizational levels and organizational performance.

The initial purpose of this research was to investigate the role of social media on enhancing the social capital and organizational knowledge management and focus on organizational knowledge quality and performance that has not been considered at all in previous research. Moreover, by influencing knowledge management, it improves organizational knowledge and its financial and innovative performance, because the most essential and critical process in organizational knowledge management is the quality of knowledge created and stored in organizations.

As mentioned above, this study highlights both the potential and limitations of social media in promoting organizational knowledge management. Businesses must consciously manage the assimilation and use of social media to benefit from them. The authors position the study at the intersection of social media, social capital, and knowledge management and explicate how social media works through social capital and organizational knowledge management efforts to affect knowledge quality. This manuscript is arranged as follows: the literature review is covered in Section 2 and the hypothesis development and research methodology are detailed in Sections 3 and 4. In Section 5, the structural model development is highlighted. In Section 6, results are discussed along with the implication of the presented research. Lastly, Section 7 covers the conclusion, limitations, and future scope of the study.

\section{Literature Review}

\subsection{Financial Performance}

Organizational performance is a main concept that encompasses what the company produces and the areas in which it interacts. In other words, organizational performance refers to how organizational missions, tasks, and activities are performed [11]. In today's competitive environment, businesses are trying to thrive and adapt to change by creating a sustainable competitive advantage by improving organizational performance. Most previous studies on organizational performance have been based on financial performance. Financial performance was measured by financial indicators such as return on investment, financial turnover, profitability, liquidity index, etc. [12].

Financial statements have data about the state of the organization's assets. The financial statements are comprised of five sections-specifically, balance sheet, profit and loss statement, cash flow statement, statement of owner's equity, and note of financial report. The reason for a financial statement investigation is to rate the possibilities and 
dangers of the organization [13]. By assessing the organization's possibilities and dangers, the organization can finish up an investigation of the organization's financial condition in a specific timeframe [14].

\subsection{Innovative Performance}

Innovation is the most crucial source of competitive advantage because it can lead to the presentation of new products that better meet customers' needs, improve the quality of existing products, or reduce the cost of production requested by customers [15]. Innovation can be defined as the adaptation of an idea or behavior that is new to the organization. At present, innovations provide a mechanism by which business entities maintain and improve their position in the market. According to Cooper (1984), innovation is a way of adapting to the environment [16]. From this perspective, innovation means that organizations need to make more efforts to adapt to environmental changes. Innovation affects the financial performance of the company because, in any activity, innovation is included, and there are reactions in the market that can lead to gaining a competitive advantage and creating a market position for business entities. Therefore, the impact of innovation should be reflected in the company's value and financial performance [17].

Innovation performance describes the "successful implementation of creative ideas within an organization"; therefore, the concept is closely associated with the workforce's organizational learning capacity [18]. Innovation performance helps firms to successfully introduce new products and services, providing vital lifeblood to the organizations. Organizations, from time to time, need the advancement of activities in order to attain a competitive advantage. Along with learning capability, the adoption of information technology significantly influences the innovation performance through which organizations become competent and efficient [19].

\subsection{Knowledge Management}

Knowledge management is a new term that has found an important place in management theory and science, and through which an organization can achieve a competitive advantage in the production and organization of knowledge and improve its performance [20]. Knowledge management is increasingly considered an essential and vital element in the strategy of organizations. Knowledge management involves various processes, such as the creation of new knowledge, knowledge acquisition from external sources, and storing knowledge in documents and databases [21]. There are several definitions of knowledge management, but one of the comprehensive definitions is the definition of Turban, according to which knowledge management is the creation and storage of knowledge and its distribution in such a way that it can be used in the organization [22].

The American Product and Quality Center (APQC) also defines knowledge management as a set of emerging strategies and approaches for creating, maintaining, and using knowledge assets (including individuals and information) that allow knowledge to flow from individuals at the right time so that they can use these assets to create more value for the institution and the organization [23,24]. For organizations engaging in knowledge management, one of their primary concerns has been the lack of employee participation, especially $[25,26]$. Consequently, research efforts in knowledge management have consistently focused on how to motivate knowledge contributions to increase the volume of organizational knowledge assets. Several proposals for the classification of the main definition of knowledge management have been considered and their connections and differences discussed and, in this research, the American approach of KM and explicit knowledge was used.

\subsection{Quality of Knowledge Management}

The quality of knowledge is essential for selecting and using existing and offered knowledge in an organization [27]. On the other hand, the need for different information for any organization's survival increases due to increasing complexity, dynamism, and 
environmental changes. Due to the exponential growth of information and its short validity, appropriate tools and methods are required to ensure the quality of knowledge [28]. Therefore, considering the importance of knowledge quality, knowledge quality assessment is essential and necessary to verify the organization's information, and it is necessary to manage this critical issue correctly and effectively by creating appropriate tools (structure, tools, people, etc.) [29].

In explaining the quality of knowledge, we considered two conditions. Firstly, we acknowledge that several definitions in the literature do not include our definition, such as definitions of the legal/implicit and observational and non-observational dimensions of Teece [13]. In the discussion of knowledge acquisition, the main focus is on the role of formal and informal networks and the capacity to absorb useful and innovative knowledge [30]. It is necessary to explain that absorption capacity is one of the prominent scientific research topics. This concept means the gradual acquisition of recognition as a driving force for the company to gain a competitive advantage [31]. Most studies have also considered innovation as the output of absorption capacity and as a mediator between innovation and external knowledge flow [13].

\subsection{Social Capital}

In examining the historical background of the concepts of social capital, we found that this concept was first used in educational materials; and social capital, in its current sense, has been used since the 1920s and has gradually expanded. Social capital includes the institutions, relationships, attitudes, values, and norms governing behavior and interactions between individuals [29]. In short, social capital is the sum of all relationships, interactions, values, and norms that facilitate collective action and make it possible to achieve individual and collective goals in an atmosphere of cooperation and satisfaction. Porter (1998) defined social capital as actors' ability to acquire and retain resources (including organizational knowledge) through membership in social networks. According to Nahapit and Gushal (1998), social capital is one of the essential organizational capabilities and assets that can help organizations create and share knowledge and create a "sustainable advantage" for them compared to other organizations. According to them, with an organizational approach, different aspects of social capital are placed in three categories [32], including a cognitive element, structural element, and relationship element.

Value-added intellectual coefficient components (i.e., human capital, structural capital, and capital employed) significantly explained asset turnover and return on assets but failed to predict the return on equity outcome. Additionally, asset turnover was negatively influenced by structural capital and positively influenced by capital employed. The return on assets was mostly affected by variations in human capital. Intellectual capital did not predict market-to-book value or investment decisions. These results were analyzed in Chowdhury [33]. The purpose of this paper, the first of its kind, was to investigate the relationship between the intellectual capital efficiency, and organizational performance of the pharmaceutical sector in Bangladesh, an emerging economy that enjoys trade-related aspects of intellectual property rights (TRIPS) relaxation.

\subsection{Social Media}

Despite the wide range of social media definitions, the focus of most of them has been on the two elements of sharing and interaction. Some definitions highlight the production and dissemination of content and consider social media as a tool by which users produce video, audio, text, or multimedia and publish and share it on social media [34]. This definition defines social media instances and includes sites based on user participation and user-generated content. In another definition, social media refers to any site or web service that has the feature of being "social" or uses the web. Blogs, social networks, social news sites (users commenting and interacting with news and events), wikis, and examples belong to this group [35]. However, in recent years, the arrival of new media and the increase in the number of communication channels available to people in society 
has led to the end of the single media era, and today audience members usually interact with several media and are not solely a consumer of one media platform, rather, they create a combination of their desired media [35]. Social media can be used to manage information flow in teams, thereby empowering knowledge management, which can be linked to innovation. Ali et al., [36], developed a model to test the influence of social media on transitive memory systems, absorptive capacities (potential and realized capacity), and team innovation performance. Partial least squares analysis on 61 software development teams indicated the positive impact of social media on transitive memory system and potential and realized absorptive capacity, which in turn can influence team innovation performance. This article presents theoretical contributions and describes implications for social media adoption in knowledge-intensive teams.

\section{Hypothesis Development}

Numerous studies have shown the positive effect of social media on social capital. Similarly to electronic communications, social media can create new online communications, which positively affects the structural dimension of social capital [37-39]. As organizations increasingly use social media to connect with customers, suppliers, competitors, and other industry partners, they can improve internal communication and interaction, which increases structural capital. A study of past research revealed that electronic communications can foster trust and, in fact, strengthen the communication dimension of social capital. Even in text-based and asynchronous communication that seems weak, the principle of honesty-based competence and trust can be formed, and the emotional support between members and the sense of belonging can be significantly strengthened. Social media facilitates knowledge sharing by supporting the development of the cognitive dimension of social capital and the importance of social media becomes more apparent when the organization's employees are geographically distant [37]. Figure 1 shows an overview of the variables that this study aimed to examine.

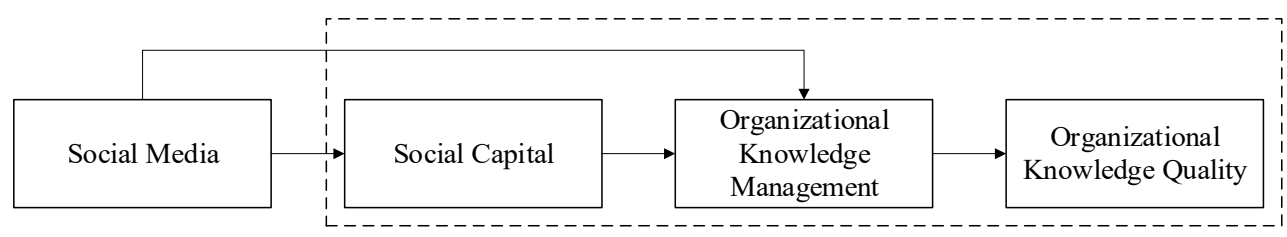

Figure 1. Tsai and Ghoshal model [3].

There are many frameworks for knowledge management processes, but experts have agreed on three steps: knowledge creation, knowledge sharing, and knowledge application. Knowledge creation is defined as the development and creation of knowledge resources across the boundaries of a company's tasks [35]. Knowledge sharing refers to the extent to which a company's knowledge resources are exchanged across task boundaries. Knowledge application also refers to the extent to which knowledge resources are exploited across functional boundaries. This capability is based on decision making and problem solving and allows the company to respond effectively and efficiently to environmental changes. There are various approaches to knowledge management [35]. From a more comprehensive perspective, can classify different approaches to knowledge management can be classified as follows: mechanical approaches, cultural/behavioral approaches, and systematic approaches [24]. The present study emphasizes the systematic approach that focuses on the whole organization and includes knowledge management quality [40]. In general, it can be said that social media creates an opportunity for employees to increase their trust, cooperation, and interaction by creating a bridge between time and space [2]. Raudeliuniene et al., [41] analyzed the impact of information technologies and social networks on knowledge management processes in Middle Eastern audit and consulting companies. Scientific literature analysis, structural equation modeling, and expert evaluation (structured questionnaire) were used to develop the research model, collect data from the audit and 
consulting companies' experts, and test the research hypotheses. The results supported the hypotheses, stating that information technologies and social networks positively affect the knowledge management cycle, including five processes (acquisition, creation, storage, sharing, and application).

Given the above, the following hypotheses can be assumed:

Hypothesis 1. As the levels of organizational social media integration increase, the structural dimension of organizational social capital increases.

Hypothesis 2. As the levels of organizational social media integration increase, the relationship dimensions of organizational social capital increase.

Hypothesis 3. As the levels of organizational social media integration increase, the cognitive dimension of organizational social capital increases.

The sharing of knowledge through social media requires a complicated process, and several studies have highlighted the importance of social media within organizations. According to previous research, social media use leads to the timely integration of knowledge and the creation different types of knowledge [42]. Today, knowledge management is inextricably linked to technological elements, as information and communication technologies are increasingly used to improve employee relationships and make it easier for employees to access documents in organizations, as various studies have pointed out. Some social media technologies have been created to promote knowledge sharing in organizations (online blogging) and knowledge creation (such as wikis), and some have been created to connect people (such as Facebook and LinkedIn), all of which aim to make knowledge more comfortable to access. Geissinger et al., [43] investigated the social media analytics for knowledge acquisition of market and non-market perceptions in the sharing economy. Using a methodological approach called social media analytics (SMA) to explore the case of Foodora, 3250 items of user-generated content in social media were systematically gathered, coded, and analyzed. The findings indicated that, while Foodora appears to be a viable provider in the marketplace, there is mounting public concern about the working conditions of its employees.

Moreover, bridging the gap between knowledge seekers and knowledge holders in organizations. Many studies have also shown that social media facilitates communication, collaboration, and innovation in organizations. Thus, social media can affect employee relations and employee relations with organizational documents, affecting organizational knowledge management [44].

Hypothesis 4. The level of social media integration in organizations has a significant relationship with the organizations' emphasis on knowledge management.

According to previous studies, social capital can increase the organization's ability to manage knowledge because it creates the capacity to diversify tasks. The existence of social capital can increase knowledge, preparation, and compilation of knowledge and its transfer. Organizations help in the combination and exchange of resources, encouraging cooperative behaviors and more effective collective activities. These measures are the basis for applying knowledge management in organizations. In their research, Helena et al. examined the effects of social capital on critical customers' relationships with knowledge acquisition and knowledge use. They concluded that social interaction and the dimensions of the link between social capital networks and knowledge acquisition, which are knowledge management processes, are widely related [45]. Jarmooka et al. [46] investigated the mapping of information and communication technologies and knowledge management processes with company innovation. The method was a quantitative survey of 148 industry managers. The data were refined through confirmatory factor analysis. The hypotheses were evaluated by regression equations and parameter estimates. The findings were 
identified by the magnitude of the effect sizes. The findings indicated key emerging relationships and then proposed a conceptual model validated by the analysis of the survey evidence. The study identified that investment in ICT and KMP has a positive impact on innovation performance.

Numerous studies have shown that the three dimensions of social capital are interrelated [29]. Communication capital is rooted in cognitive capitalism. Tsai and Gushal (1998) also showed that structural capital had a positive and significant effect on communication capital and a small effect on cognitive capital in a large multinational electronics company [29]. Also, Byungjin and Byunghak (2013), in their research, concluded that structural capital has a positive and significant effect on communication and cognitive capital, and also that communication capital has a positive and significant effect on cognitive capital. Therefore, according to the issues mentioned above, the following hypotheses were considered.

Hypothesis 5. There is a positive and significant relationship between the structural and cognitive dimensions of organizations' social capital.

Hypothesis 6. There is a positive and significant relationship between structural dimensions and social capital relations.

Social capital increases knowledge acquisition, acquisition, and creation in the organization by increasing access to external sources of knowledge, knowledge exchange, and absorption and increasing knowledge transfer efficiency.

Hypothesis 7. Organizational structural capital levels have a positive and significant relationship with organizations' emphasis on knowledge management.

Hypothesis 8. There is a positive and significant relationship between the cognitive dimensions and organizations' social capital relationships.

Hypothesis 9. Organizational levels of organizations have a positive and significant relationship with organizations' emphasis on knowledge management.

Hypothesis 10. Relationship capital levels of organizations have a positive and significant relationship with organizations' emphasis on knowledge management.

Social capital creates channels of communication to promote exchanges, create, and recombine knowledge. In this regard, social capital empowers knowledge management activities such as knowledge acquisition, transfer, and sharing, which increases the quality of knowledge management [47]. As long as social capital facilitates organizational knowledge management, organizations should use it as a resource to deal with productivity. Given the above, the following hypothesis was considered for this research:

Hypothesis 11. There is a positive and significant relationship between organizations' emphasis on knowledge management and their organizational knowledge quality.

According to the research goal, the analysis of the proposed definitions of knowledge management showed that many are similar in one sense, that knowledge management leads to improved organizational performance $[6,8,45]$. The central idea is that if knowledge is managed consciously, it will increase organizational knowledge and lead to superior performance. Many researchers consider only the financial aspects of an organization's performance. Simultaneously, non-financial outcomes such as process outcomes, new service development, capacity building, training, and development are also important. At the same time, many consider this relationship difficult to understand, especially in terms of the non-financial aspects of performance. In other words, innovative performance in 
the literature is considered one of the most critical drivers of the organization's functional aspects due to the continuous efforts to adapt to a competitive environment. Soo et al. (2004) also showed that knowledge quality positively and significantly affects innovative performance and financial performance. Therefore, according to the aforementioned issues, the following hypotheses were considered [30]. Audretsch and Belitski [48] investigated knowledge complexity and firm performance. This study aimed to discuss and investigate to what extent the interplay between the domains of knowledge complexity (managerial, strategic, and operational) facilitate firm performance and the role of organizational resilience in this relationship. Compared to other acumens of knowledge complexity, managerial and operational acumens contributed most the most to a firm's performance (sales and productivity).

Hypothesis 12. The quality of organizational knowledge increases the innovative performance of organizations.

Hypothesis 13. The quality of organizational knowledge increases the financial performance of companies.

According to Cooper (1984), innovation is a way of adapting to the environment. From this perspective, innovation means that business entities must make more efforts to adapt to the environment. Innovation affects the financial performance of the company. Every business activity includes innovation and market reactions that can lead to a competitive advantage and market position for business entities, so the impact of innovation should be reflected in its value and financial performance. According to Cabrilo et al. [49], internal relationships and trust embedded in firms' relationships played a significant role in the innovation performance of Taiwanese enterprises and revealed a more closed approach to innovation. IT advancement has an important role in amplifying the effects of internal and external relationships and trust formation on innovation performance.

Therefore, according to the issues mentioned above, the next hypothesis was considered.

Hypothesis 14. Innovative performance of organizations has a positive and significant effect on their financial performance.

\section{Conceptual Model}

According to the above, the conceptual model is presented as follows and as Figure 2 shows, social media integration was considered as an independent variable; social capital variables and organizational emphasis on knowledge management, organizational knowledge quality, and performance innovation were considered as mediating variables; and financial performance was considered as a dependent variable.

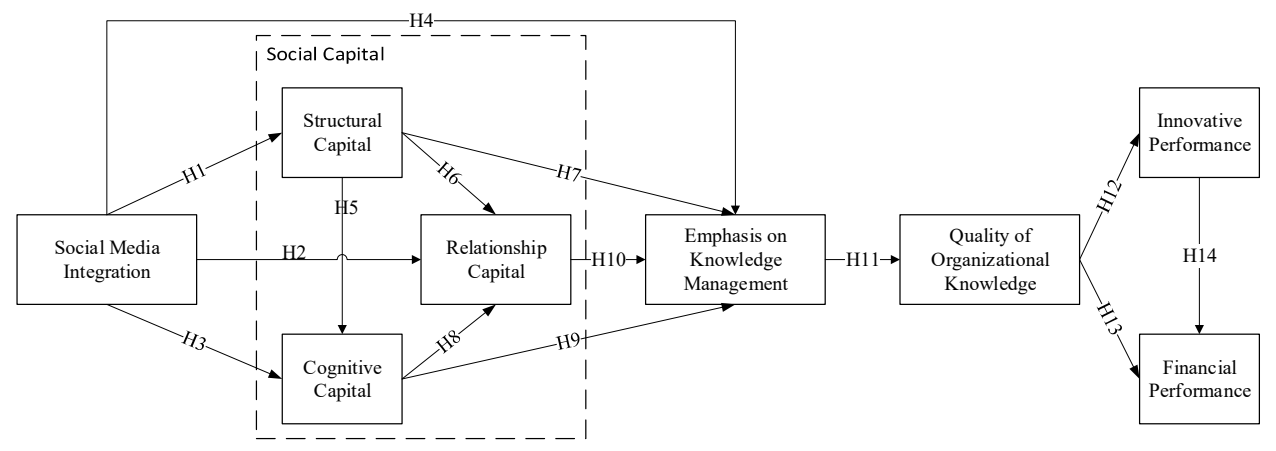

Figure 2. Conceptual model of research.

\section{Research Methodology}

The present study utilized descriptive survey research. The statistical population of this study was the supervisory staff of Bank Saderat of Mazandaran province in Iran. For 
sampling, a simple random sampling method was used, and since the statistical population was limited to 750 people, according to Cochran's formula for a limited population, the appropriate number of samples was 254 people. For this purpose, 280 questionnaires were distributed and collected, and used. Data were collected through Salim and Suleiman's (2001) questionnaire with five items - three items related to innovative performance and two items used to measure financial and innovative performance [50]. Additionally, to measure the quality of knowledge, Durcikava and Gary's (2009) questionnaire with three items was used to measure the organization's emphasis on knowledge management [51] and Kearn and Sabherwal's (2006) questionnaire with three items was used [52]. Bharati et al.'s (2014) questionnaire was used with six items-two items for structural capital, two items for relational capital, and two items for cognitive capital to measure social capital [53]. Finally, Fichman's (2001) questionnaire with two items was used to measure the variable of organizational social media integration [54].

\section{Finding}

In the first part of the questionnaire, the demographic information of the respondents, including gender, level of education, and work experience, was examined, and in the second part, the research variables were evaluated, and all variables were compared with a range of five Likert options. Composite reliability (CR), Cronbach's alpha, and averagevariance extracted (AVE) were performed to assess the questionnaire's reliability, and divergent validity was used to assess the validity. The results can be seen in Table 1.

Table 1. Results of reliability analysis.

\begin{tabular}{ccccc}
\hline Variable & $\begin{array}{c}\text { Number of } \\
\text { Questions }\end{array}$ & Cronbach's Alpha & CR & AVE \\
\hline Integration & 2 & 0.708 & 0.836 & 0.718 \\
Structural capital & 2 & 0.725 & 0.845 & 0.732 \\
Cognitive capital & 2 & 0.742 & 0.862 & 0.736 \\
Relationship capital & 2 & 0.698 & 0.811 & 0.564 \\
KM & 3 & 0.770 & 0.893 & 0.602 \\
Knowledge quality & 3 & 0.835 & 0.932 & 0.692 \\
Innovative performance & 3 & 0.751 & 0.866 & 0.671 \\
Financial performance & 2 & 0.787 & 0.904 & 0.825 \\
Total & $\mathbf{1 9}$ & $\mathbf{0 . 8 8 9}$ & - & - \\
\hline
\end{tabular}

Table 1 shows the coefficients of the internal compatibility indices. All composite reliability coefficients and Cronbach's alpha were more significant than the critical limit of 0.7 , and all the mean variances of the extracted were more significant than 0.5 , so it can be said that the measurement models were within acceptable limits. The next step was to examine the measurement models in terms of validity and assess the measurement models' ability to measure the phenomenon. A powerful way to do this is to evaluate the construct validity by evaluating the measurement models' divergent and convergent validity. Convergent validity examines the scores of indicators defined to measure a structure. Convergent validity means that the set of references explains the main structure. If the criteria show the same results, then there is convergent validity.

Table 2 shows that the factor loads of each structure's criteria were more than the external structure, indicating the convergent validity between each structure's criteria. Divergent validity has also been used to investigate the effect of the alignment of variables. Divergent validity, or diagnostic validity, complements convergent validity, which indicates the degree of differentiation of markers of a particular structure from markers of other structures in the same model. In PLS modeling, one criterion for the appropriateness of diagnostic validity is that the structure should have the most common variance with its markers rather than with other structures in a given model. To evaluate the diagnostic validity, Fresnel and Larker (1981) suggested using the mean variance of the extracted AVE, i.e., the mean of the common variance between the structure and its markers. They 
recommended values of 0.5 and above for AVE, which means that the structure explains about $50 \%$ or more of its markers' variance. The mean variance extracted must be greater than the common variance of that structure and the other structures in the model, i.e., the correlation between the two structures. In the correlation matrix, the correlation between the different structures in the non-diagonal elements of the right matrix and the mean variance's square root extracted for each structure along the diagonal line is shown. For diagnostic validity to be appropriate, diagonal elements must be significantly larger than non-diagonal elements in columns and rows.

Table 2. Combined and reciprocal factor loading.

\begin{tabular}{|c|c|c|c|c|c|c|c|c|c|c|c|}
\hline & 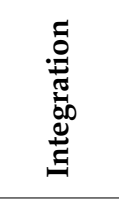 & 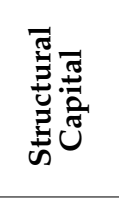 & 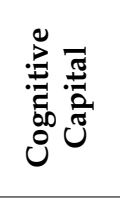 & 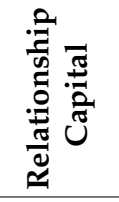 & $\sum$ & 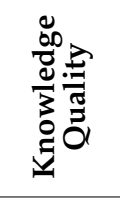 & 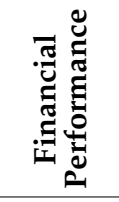 & 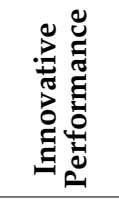 & 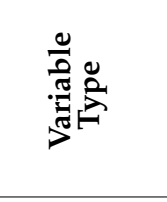 & w & $\begin{array}{l}\frac{0}{J} \\
2 \\
2\end{array}$ \\
\hline OSMA1 & 0.848 & -0.069 & 0.132 & 0.19 & -0.335 & -0.207 & 0.226 & -0.092 & Formative & 0.051 & $<0.001$ \\
\hline OSMA2 & 0.86 & -0.111 & 0.156 & 0.201 & -0.280 & -0.311 & 0.342 & -0.110 & Formative & 0.051 & $<0.001$ \\
\hline STR1 & 0.126 & 0.811 & -0.244 & -0.234 & -0.038 & 0.232 & -0.219 & 0.28 & Reflective & 0.051 & $<0.001$ \\
\hline STR2 & 0.145 & 0.833 & -0.189 & 0.17 & -0.070 & 0.179 & -0.269 & 0.227 & Reflective & 0.051 & $<0.001$ \\
\hline COG1 & 0.148 & 0.071 & 0.88 & -0.030 & -0.098 & -0.525 & -0.098 & -0.056 & Reflective & 0.051 & $<0.001$ \\
\hline COG2 & 0.171 & 0.06 & 0.875 & -0.109 & -0.147 & -0.221 & 0.381 & -0.026 & Reflective & 0.051 & $<0.001$ \\
\hline RE1 & 0.026 & 0.012 & 0.272 & 0.751 & 0.327 & -0.395 & 0.226 & -0.439 & Reflective & 0.051 & $<0.001$ \\
\hline RE2 & 0.024 & 0.095 & 0.161 & 0.774 & 0.209 & 0.042 & 0.144 & -0.183 & Reflective & 0.051 & $<0.001$ \\
\hline OEKM1 & 0.141 & -0.175 & 0.334 & 0.385 & 0.759 & 0.364 & 0.222 & 0.145 & Reflective & 0.051 & $<0.001$ \\
\hline OEKM2 & -0.094 & 0.149 & 0.034 & -0.030 & 0.838 & 0.182 & 0.022 & 0.025 & Reflective & 0.051 & $<0.001$ \\
\hline OEKM3 & -0.036 & 0.354 & 0.388 & -0.367 & 0.727 & 0.091 & -0.175 & 0.059 & Reflective & 0.051 & $<0.001$ \\
\hline KQ1 & 0.104 & -0.052 & 0.023 & -0.114 & -0.093 & 0.878 & -0.089 & -0.133 & Reflective & 0.051 & $<0.001$ \\
\hline KQ2 & -0.253 & 0.146 & -0.203 & 0.05 & 0.229 & 0.71 & 0.125 & 0.047 & Reflective & 0.051 & $<0.001$ \\
\hline KQ̄3 & 0.099 & -0.064 & 0.138 & 0.072 & -0.091 & 0.896 & -0.012 & 0.089 & Reflective & 0.051 & $<0.001$ \\
\hline IP1 & -0.048 & -0.031 & 0.034 & 0.113 & -0.161 & 0.444 & 0.805 & -0.182 & Reflective & 0.051 & $<0.001$ \\
\hline IP2 & -0.152 & 0.217 & 0.003 & -0.094 & 0.218 & -0.456 & 0.754 & 0.074 & Reflective & 0.051 & $<0.001$ \\
\hline IP3 & 0.171 & -0.156 & -0.033 & -0.022 & -0.039 & -0.014 & 0.892 & 0.187 & Reflective & 0.051 & $<0.001$ \\
\hline FP1 & 0.16 & 0.112 & 0.058 & -0.032 & 0.05 & 0.022 & -0.023 & 0.908 & Reflective & 0.051 & $<0.001$ \\
\hline FP2 & 0.201 & 0.107 & 0.079 & -0.089 & 0.042 & -0.132 & -0.060 & 0.886 & Reflective & 0.051 & $<0.001$ \\
\hline
\end{tabular}

As can be seen in Table 3, the value of the AVE root of the latent variables in the present study, which are located in the cells located in the primary diameter of the matrix, was greater than the value of the correlation between those arranged in the lower and right cells of the primary diameter. Therefore, it can be stated that in the present study, structures (latent variables) in the model had more interaction with their indicators than with other structures; therefore, the divergent validity of the model was appropriate.

Due to the present research questionnaire's reliability and validity, in the next section, we examined the research hypotheses through a structural model.

In order to test the research hypothesis, the path analysis technique has been used. Figure 2 shows the structural equation model of the research hypotheses and Table 4 summarizes the results of the research hypotheses. 
Table 3. Divergent validity results.

\begin{tabular}{ccccccccc}
\hline & Integration & $\begin{array}{c}\text { Structural } \\
\text { Capital }\end{array}$ & $\begin{array}{c}\text { Cognitive } \\
\text { Capital }\end{array}$ & $\begin{array}{c}\text { Relationship } \\
\text { Capital }\end{array}$ & KM & $\begin{array}{c}\text { Knowledge } \\
\text { Quality }\end{array}$ & $\begin{array}{c}\text { Financial } \\
\text { Performance }\end{array}$ & $\begin{array}{c}\text { Innovative } \\
\text { Performance }\end{array}$ \\
\hline OSMA & 0.847 & 0.426 & 0.521 & 0.422 & 0.519 & 0.411 & 0.536 & 0.514 \\
STR & 0.426 & 0.856 & 0.308 & 0.434 & 0.396 & 0.128 & 0.206 & 0.37 \\
COG & 0.452 & 0.308 & 0.858 & 0.331 & 0.471 & 0.571 & 0.638 & 0.615 \\
RE & 0.422 & 0.434 & 0.331 & 0.751 & 0.498 & 0.376 & 0.278 & 0.351 \\
OEKM & 0.519 & 0.396 & 0.471 & 0.498 & 0.776 & 0.331 & 0.448 & 0.531 \\
KQ & 0.411 & 0.128 & 0.571 & 0.376 & 0.331 & 0.832 & 0.641 & 0.472 \\
IP & 0.537 & 0.206 & 0.638 & 0.278 & 0.448 & 0.641 & 0.82 & 0.637 \\
FP & 0.514 & 0.37 & 0.615 & 0.351 & 0.531 & 0.472 & 0.637 & 0.908 \\
\hline
\end{tabular}

Table 4. Results of research hypotheses testing.

\begin{tabular}{|c|c|c|c|c|}
\hline & Hypothesis & Path Coeficient $(\beta)$ & $p$-Value & Result \\
\hline 1 & Integration $\leftarrow$ Structural capital & 0.43 & $<0.01$ & Approved \\
\hline 2 & Integration $\leftarrow$ Relationship capital & 0.3 & $<0.01$ & Approved \\
\hline 3 & Integration $\leftarrow$ Cognitive capital & 0.5 & $<0.01$ & Approved \\
\hline 4 & Integration $\leftarrow \mathrm{KM}$ & 0.24 & $<0.01$ & Approved \\
\hline 5 & Structural capital $\leftarrow$ Cognitive capital & 0.12 & $<0.01$ & Approved \\
\hline 6 & Structural capital $\leftarrow$ Relationship capital & 0.28 & $<0.01$ & Approved \\
\hline 7 & Structural capital $\leftarrow \mathrm{KM}$ & 0.24 & $<0.01$ & Approved \\
\hline 8 & Cognitive capital $\leftarrow$ Relationship capital & 0.18 & $<0.01$ & Approved \\
\hline 9 & Cognitive capital $\leftarrow \mathrm{KM}$ & 0.16 & $<0.01$ & Approved \\
\hline 10 & Relationship capital $\leftarrow \mathrm{KM}$ & 0.29 & $<0.01$ & Approved \\
\hline 11 & $\mathrm{KM} \leftarrow$ Knowledge quality & 0.4 & $<0.01$ & Approved \\
\hline 12 & Knowledge quality $\leftarrow$ Innovative performance & 0.65 & $<0.01$ & Approved \\
\hline 13 & Knowledge quality $\leftarrow$ Financial performance & 0.17 & $<0.01$ & Approved \\
\hline 14 & Innovative performance $\leftarrow$ Financial performance & 0.53 & $<0.01$ & Approved \\
\hline
\end{tabular}

As can be seen in Table 4, all hypotheses were confirmed due to $p<0.01$. Figure 3 shows the results of the research hypotheses:

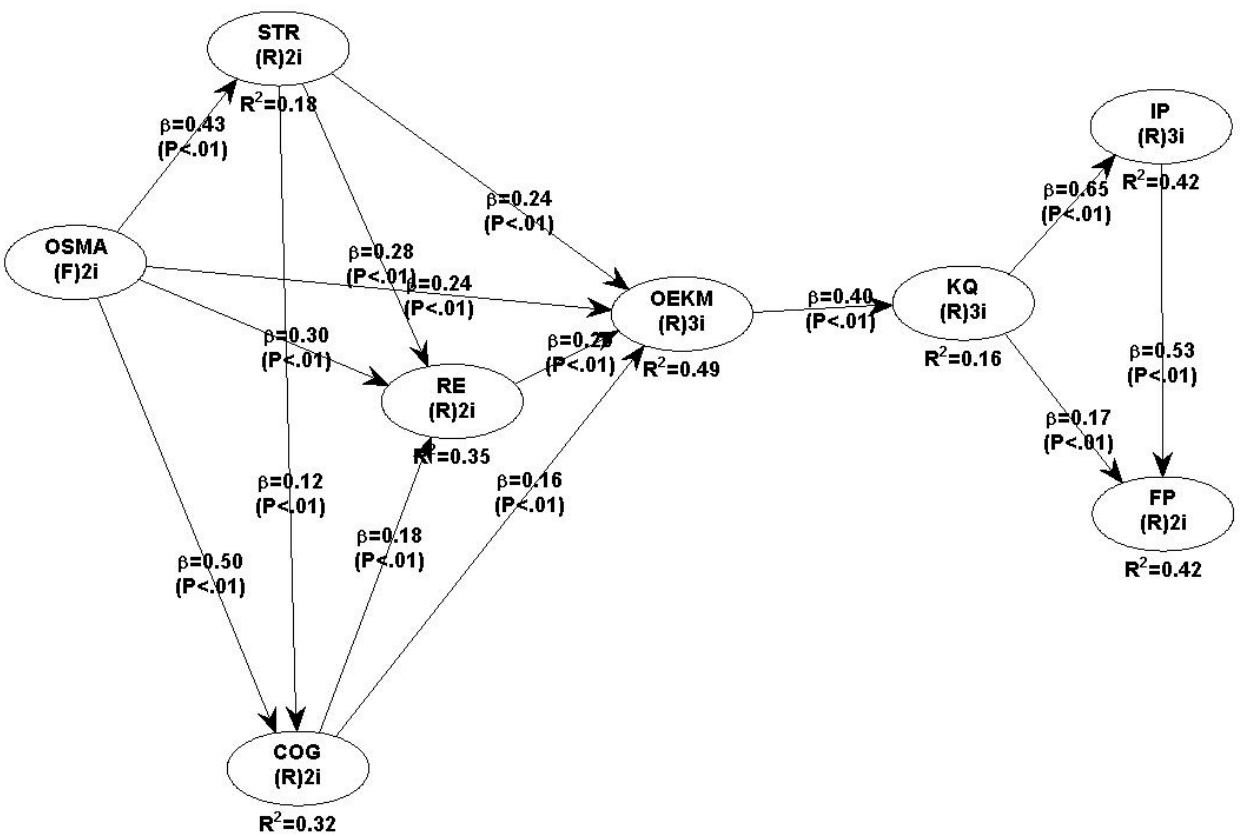

Figure 3. Results of model testing (output of WarpPLS software). 


\section{Discussion}

It is possible to study PLS and research hypotheses' structural patterns by examining the path coefficients (Beta) and R2 values. Path coefficients are used to determine each of the predictor variables' contributions in explaining the variance of the criterion variable, and the values of $\mathrm{R} 2$ indicate the variance of the criterion variable explained by the predictor variables. Chen (1998) introduced three values of $0.19,0.33$, and 0.67 as the criterion values for weak, medium, and strong values of R2. Also, the overall fit index of the PLS pattern is the GOF index, and it can be used to check the validity or quality of the PLS pattern in general. This index is between zero and one, and values close to one indicate the appropriate quality model. Wetzels et al. (2009) introduced three values of $0.01,0.25$, and 0.36 as weak, medium, and strong values for GOF. Table 5 presents the model fit criteria.

Table 5. Model fit criteria.

\begin{tabular}{cccc}
\hline Fit Criterion & Acceptable Value & Result & $p$-Value \\
\hline Average path coefficient (APC) & Good if $p<0.05$ & 0.321 & $<0.01$ \\
Average R-squared (ARS) & Good if $p<0.05$ & 0.335 & $<0.01$ \\
Average adjusted R-squared (AARS) & Good if $p<0.05$ & 0.331 & $<0.01$ \\
Good Fit Index (GoF) & small $\geq 0.1$ medium $\geq 0.25$, & 0.480 & - \\
Average block VIF (AVIF) & large $\geq 0.36$ & 1.454 & - \\
\hline
\end{tabular}

As Table 5 shows, the fit criteria had excellent values. The essential fit index in working with PLS software, i.e., the good of fitness index (GOF), had a suitable value (0.480), which indicates a good fit of the conceptual research model. Other criteria were also in good condition. For example, the average path coefficient index (APC) and the average determination coefficient index (ADC) had values less than 0.001 , which indicated a good fit of the model.

Moreover, the mutual relations between the organization's employees were persuasive, and the last two dimensions were formed in the shadow of the structural dimension of social capital. Organizational social media integration had a positive and significant effect on the structural, cognitive, and relationship dimensions of social capital; this confirmed the findings of Baharati et al. (2015). Information age organizations, especially banks, are increasingly using social media to connect with suppliers, competitors, partners, and especially their customers in the industry, which improves communication. Internal organization and interactions, which increase structural capital, help. In general, it can be said that social media creates an opportunity for employees to increase their trust, cooperation, and interaction by creating a bridge between space and time. Therefore, it is suggested that Bank Saderat provide such a platform to increase social interactions and present its customers' and employees' views and opinions by using social networks on the Internet, such as by creating internet clubs and advocacy and providing various Internet services for a like-minded environment and knowledge creation. The results showed that social media integration positively and significantly affects the organization's emphasis on knowledge management. This result is consistent with the results of Baharati et al. (2015). It is suggested that Bank Saderat strengthen social management in its organization by using social media to communicate with its employees and customers, considering the positive effect of social media integration on the organization's emphasis on knowledge management.

Social media can serve as a powerful tool for knowledge management, especially if there is a way to receive and share online messages, banners, and announcements. Such networks are far more useful to banks than commercial knowledge management software packages. Thus, social media integration allows employees to define rules and regulations themselves, connect to their favorite channels, and strengthen the organizational knowledge management process. The results showed that the three dimensions of social capital had positive and significant effects on the organization's emphasis on knowledge 
management, consistent with Ferreira and Pilati's (2013) results. Social capital increases knowledge acquisition and creation in the organization by increasing access to external sources of knowledge and increasing the efficiency of knowledge sharing. Therefore, it is suggested that Bank Saderat expand the organization's knowledge processes with more emphasis on social capital and strengthening its various dimensions.

\section{Conclusions}

Today, in addition to human, financial, and economic capital, another capital in organizations and societies has been proposed as social capital. This concept is a new sociology concept closely related to human capital as the most crucial source for organizations. Utilizing other organizational assets is also possible in the light of this capital, which indicates the importance of this capital in the organization. In the past, social capital was not a necessary competency for organizations. However, now, rapid environmental changes in information technology, growing needs for information and training, essential needs for innovation and creativity, the importance of knowledge management and quality of organizational knowledge, changing the design of flat and flexible organizations, communication between organizations, and improvement in general organizational performance require organizational leaders to establish social capital as a distinct organizational competency. Considering the above and the importance of social capital and knowledge management in the banking industry, in this study, the variables of organizational social media integration, three dimensions of social capital, quality of knowledge management, and their impacts on the financial and innovative performance of Saderat Bank Branch Management Organization Mazandaran were examined. The cognitive dimension, which expresses the links in the organization's network, the shape of the organization hierarchy and the density of the structure, and the intensity of communication in its structure, is based on other dimensions.

The organization's emphasis on knowledge management had a positive and significant effect on organizational knowledge quality. This result confirmed the research results by Baharati et al. [2], Tsai and Goshal [3], and others [36,43,46,49]. The results showed that the quality of organizational knowledge had a positive and significant effect on the organization's financial and innovative performance, consistent with the results of research by Soo et al. (2004). If knowledge is managed consciously in the organization (through social media and strengthening social capital), it will increase organizational knowledge and lead to superior performance because knowledge management promotes learning, and learning is one factor that strengthens the relationship between innovation and innovation performance. The results also showed that the quality of organizational knowledge had a much more significant impact on innovative performance than financial performance. Creating shared value for the organization and customers, which is the primary goal of knowledge management, was achieved here. The quality of organizational knowledge will lead to the development of organizational knowledge and, consequently, the provision of services with customers' intellectual participation, opinions, and ideas and increase their satisfaction and improve organizational performance. Finally, the results showed that innovative performance affected the organization's financial performance, consistent with Soo et al.'s (2004) results, which shows the importance of innovative organizations in being more efficient and effective than other organizations. In other words, the results showed that the quality of organizational knowledge management had a direct and indirect positive effect on organizational performance. It is suggested that by implementing knowledge management practices and strengthening the quality of organizational knowledge through social media, managers should support innovative and new ideas of employees and customers and encourage them to provide new ideas and cooperation to improve financial performance. It is also suggested that, in order to manage their organizational knowledge effectively, organizations should strive to strengthen social capital and mutual trust among their employees. However, in the appropriate development and management of organizational knowledge, structural and technological factors and dimensions are of great importance. Suppose organizations want to develop knowledge management in 
their organization, acquire knowledge, strengthen various social capital dimensions, and improve their performance. In that case, they must use social media and integrate its various functions and improve effective communication and interaction between members by providing the organization with the necessary infrastructure, including processes, systems, and technologies to acquire, maintain, and apply organizational knowledge.

Findings from this study suggest many opportunities for future research in this area. Future research is needed in establishing the time sequence in the proposed causal relations. For example, future research may need to collect time series data. Researchers may also consider using qualitative studies to triangulate the findings reported in this study. The findings of the positive effects are reassuring, however, the study did not concern the individual level mechanism through which social media promotes social capital and facilitates knowledge management quality and exactly how they work together to improve organizational performance. Future individual-level research in this area should further enrich the understanding of the complicated dynamics between social media, social capital, knowledge management, and knowledge quality.

Author Contributions: Conceptualization, I.M.-K. and G.K.; methodology, S.G. and G.K.; software, G.K.; validation, I.M.-K. and V.D.; formal analysis, I.M.-K.; investigation, I.M.-K. and V.D.; resources, S.G.; writing—original draft preparation, S.G. and G.K.; writing—review and editing, I.M.-K. and V.D.; visualization, S.G.; supervision, I.M.-K. All authors have read and agreed to the published version of the manuscript.

Funding: This research received no external funding.

Institutional Review Board Statement: Not applicable.

Informed Consent Statement: Not applicable.

Data Availability Statement: The data of this study is available from the authors upon request.

Conflicts of Interest: The authors declare no conflict of interest.

\section{References}

1. Afshari, L.; Nasab, A.H.; Dickson, G. Organizational culture, social capital, and knowledge management: An integrated model. Int. J. Knowl. Manag. 2020, 16, 52-66. [CrossRef]

2. Bharati, P.; Zhang, W.; Chaudhury, A. Better knowledge with social media? Exploring the roles of social capital and organizational knowledge management. J. Knowl. Manag. 2015, 19, 456-475. [CrossRef]

3. Tsai, W.; Ghoshal, S. Social capital and value creation: The role of intrafirm networks. Acad. Manag. J. 1998, 464-476.

4. Toffler, A. Powershift: Knowledge, Wealth and Violence at the Edge of the 21st Century; Bantam Books: New York, NY, USA, 1990.

5. Glazer, R. Measuring the Knower: Towards a Theory of Knowledge Equity. Calif. Manag. Rev. 1998, 40, 175-194. [CrossRef]

6. Arthur, J.B.; Huntley, C.L. Ramping up the Organizational Learning Curve: Assessing the Impact of Deliberate Learning on Organizational Performance under Gainsharing. Acad. Manag. J. 2005, 48, 1159-1170. [CrossRef]

7. Zhang, H.; Gupta, S.; Sun, W.; Zou, Y. How social-media-enabled co-creation between customers and the firm drives business value? The perspective of organizational learning and social Capital. Inf. Manag. 2020, 57, 103200. [CrossRef]

8. Hoffman, J.J.; Hoelscher, M.L.; Sherif, K. Social capital, knowledge management, and sustained superior performance. J. Knowl. Manag. 2005, 9, 93-100. [CrossRef]

9. Dumetz, L.; Gaudreault, J.; Thomas, A.; Marier, P.; Lehoux, N.; El-Haouzi, H. A Simulation Framework for the Evaluation of Production Planning and Order Management Strategies in the Sawmilling Industry. IFAC PapersOnLine 2015, 48, 622-627. [CrossRef]

10. Arab, A.; Sahebi, I.G.; Alavi, S.A. Assessing the Key Success Factors of Knowledge Management Adoption in Supply Chain. Int. J. Acad. Res. Bus. Soc. Sci. 2017, 7, 2222-6990. [CrossRef]

11. Ahrens, T.; Ferry, L. Financial resilience of English local government in the aftermath of COVID-19. J. Public Budg. Account. Financ. Manag. 2020, 32, 813-823. [CrossRef]

12. Burnard, K.J.; Bhamra, R.S. Organisational resilience: Development of a conceptual framework for organisational responses. Int. J. Prod. Res. 2011, 49, 5581-5599. [CrossRef]

13. Kostopoulos, K.; Papalexandris, A.; Papachroni, M.; Ioannou, G. Absorptive capacity, innovation, and financial performance. J. Bus. Res. 2011, 64, 1335-1343. [CrossRef]

14. Li, G.; Fan, H.; Lee, P.K.; Cheng, T. Joint supply chain risk management: An agency and collaboration perspective. Int. J. Prod. Econ. 2015, 164, 83-94. [CrossRef] 
15. Prajogo, D.; Sohal, A.S. The relationship between organization strategy, total quality management (TQM), and organization performance-The mediating role of TQM. Eur. J. Oper. Res. 2006, 168, 35-50. [CrossRef]

16. Cooper, T. Exploring strategic risk in communities: Evidence from a Canadian province. J. Enterp. Communities People Places Glob. Econ. 2012, 6, 350-368. [CrossRef]

17. Hayward, M.; Caldwell, A.; Steen, J.; Gow, D.; Liesch, P. Entrepreneurs' capital budgeting orientations and innovation outputs: Evidence from Australian biotechnology firms. Long Range Plan. 2017, 50, 121-133. [CrossRef]

18. Tseng, S.-M. The correlation between organizational culture and knowledge conversion on corporate performance. J. Knowl. Manag. 2010, 14, 269-284. [CrossRef]

19. Agarwal, S.; Erramilli, M.K.; Dev, C.S. Market orientation and performance in service firms: Role of innovation. J. Serv. Mark. 2003, 17, 68-82. [CrossRef]

20. Zheng, W. The Impact of Organizational Culture, Structure, and Strategy on Knowledge Management Effectiveness and Organizational Effectiveness. Ph.D. Thesis, The University of Minnesota, Minneapolis, MN, USA, 2005.

21. Dischner, S. Organizational structure, organizational form, and counterproductive work behavior: A competitive test of the bureaucratic and post-bureaucratic views. Scand. J. Manag. 2015, 31, 501-514. [CrossRef]

22. Zheng, W.; Yang, B.; McLean, G.N. Linking organizational culture, structure, strategy, and organizational effectiveness: Mediating role of knowledge management. J. Bus. Res. 2010, 63, 763-771. [CrossRef]

23. Arab, A.; Sahebi, I.G.; Modarresi, M.; Ajalli, M. A Grey DEMATEL approach for ranking the KSFs of environ-mental management system implementation (ISO 14001). Calitatea 2017, 18, 115.

24. Ha, T.M.; Nguyen, P.K. Social capital, knowledge sharing and firm performance. Manag. Sci. Lett. 2020, 10, 2923-2930. [CrossRef]

25. Meidute-Kavaliauskiene, I.; Davidaviciene, V.; Ghorbani, S.; Sahebi, I. Optimal Allocation of Gas Resources to Different Consumption Sectors Using Multi-Objective Goal Programming. Sustainability 2021, 13, 5663. [CrossRef]

26. Sahebi, I.; Masoomi, B.; Ghorbani, S.; Uslu, T. Scenario-based designing of closed-loop supply chain with uncertainty in returned products. Decis. Sci. Lett. 2019, 8, 505-518. [CrossRef]

27. Liu, M.T.; Wong, I.A.; Shi, G.; Chu, R.; Brock, J.L. The impact of corporate social responsibility (CSR) performance and perceived brand quality on customer-based brand preference. J. Serv. Mark. 2014, 28, 181-194. [CrossRef]

28. Ugboro, I.O.; Obeng, K. Top management leadership, employee empowerment, job satisfaction, and customer satisfaction in TQM organizations: An empirical study. J. Qual. Manag. 2000, 5, 247-272. [CrossRef]

29. Lester, M. Social Capital and Value Creation: A Replication of 'The Role of Intrafirm Networks' by Wenpin Tsai and Sumantra Ghoshal. Am. J. Bus. Manag. 2013, 2, 106-113. [CrossRef]

30. Soo, C.W.; Devinney, T.; Midgley, D.F. The Role of Knowledge Quality in Firm Performance. In Organizations as Knowledge Systems; Springer Science and Business Media LLC: Berlin/Heidelberg, Germany, 2004; pp. 252-275.

31. Lichtenthaler, U. Absorptive capacity, environmental turbulence, and the complementarity of organizational learning processes. Acad. Manag. J. 2009, 52, 822-846. [CrossRef]

32. Miković, R.; Petrović, D.; Mihić, M.; Obradović, V.; Todorović, M. The integration of social capital and knowledge managementThe key challenge for international development and cooperation projects of nonprofit organizations. Int. J. Proj. Manag. 2020, 38, 515-533. [CrossRef]

33. Chowdhury, L.A.M.; Rana, T.; Azim, M.I. Intellectual capital efficiency and organisational performance. J. Intellect. Cap. 2019, 20, 784-806. [CrossRef]

34. Eyong, M. Creating a Competitive Supply Chain: Evaluating the Impact of Lean \& Agile Supply Chain. Master's Thesis, Mälardalen University, Västerås, Sweden, 2009.

35. Swanson, E.; Kim, S.; Lee, S.-M.; Yang, J.-J.; Lee, Y.-K. The effect of leader competencies on knowledge sharing and job performance: Social capital theory. J. Hosp. Tour. Manag. 2020, 42, 88-96. [CrossRef]

36. Ali, A.; Bahadur, W.; Wang, N.; Luqman, A.; Khan, A.N. Improving team innovation performance: Role of social media and team knowledge management capabilities. Technol. Soc. 2020, 61, 101259. [CrossRef]

37. Burke, M.; Kraut, R.; Marlow, C. Social capital on Facebook: Differentiating uses and users. In Proceedings of the SIGCHI Conference on Human Factors in Computing Systems, Vancouver, BC, Canada, 7-12 May 2011; pp. 571-580.

38. McElroy, M.W.; Jorna, R.J.; Van Engelen, J. Rethinking social capital theory: A knowledge management perspective. J. Knowl. Manag. 2006, 10, 124-136. [CrossRef]

39. Baehr, C.; Alex-Brown, K. Assessing the Value of Corporate Blogs: A Social Capital Perspective. IEEE Trans. Dependable Secur. Comput. 2010, 53, 358-369. [CrossRef]

40. Hung, R.Y.Y.; Lien, B.Y.-H.; Yang, B.; Wu, C.-M.; Kuo, Y.-M. Impact of TQM and organizational learning on innovation performance in the high-tech industry. Int. Bus. Rev. 2011, 20, 213-225. [CrossRef]

41. Raudeliuniene, J.; Albats, E.; Kordab, M. Impact of information technologies and social networks on knowledge management processes in Middle Eastern audit and consulting companies. J. Knowl. Manag. 2021, 25, 871-898. [CrossRef]

42. Ko, D.-G.; Dennis, A.R. Profiting from Knowledge Management: The Impact of Time and Experience. Inf. Syst. Res. 2011, 22, 134-152. [CrossRef]

43. Geissinger, A.; Laurell, C.; Öberg, C.; Sandström, C.; Sick, N.; Suseno, Y. Social media analytics for knowledge acquisition of market and non-market perceptions in the sharing economy. J. Knowl. Manag. 2021, 25, 500-512. [CrossRef] 
44. Leana, C.; Pil, F.K. Social Capital and Organizational Performance: Evidence from Urban Public Schools. Organ. Sci. 2006, 17, 353-366. [CrossRef]

45. Ferreira, C.L.; Pilatti, L.A. Analysis of the Seven Dimensions of Knowledge Management in Organizations. J. Technol. Manag. Innov. 2013, 8, 9-10. [CrossRef]

46. Jarmooka, Q.; Fulford, R.G.; Morris, R.; Barratt-Pugh, L. The mapping of information and communication technologies, and knowledge management processes, with company innovation. J. Knowl. Manag. 2021, 25, 313-335. [CrossRef]

47. Ganguly, A.; Talukdar, A.; Chatterjee, D. Social capital, knowledge quality, knowledge sharing, and innovation capability: An empirical study of the Indian pharmaceutical sector. Knowl. Process. Manag. 2020, 27, 25-42. [CrossRef]

48. Audretsch, D.B.; Belitski, M. Knowledge complexity and firm performance: Evidence from the European SMEs. J. Knowl. Manag. 2021, 25, 693-713. [CrossRef]

49. Cabrilo, S.; Dahms, S.; Mutuc, E.B.; Marlin, J. The role of IT practices in facilitating relational and trust capital for superior innovation performance: The case of Taiwanese companies. J. Intellect. Cap. 2020, 21, 753-779. [CrossRef]

50. Salimi, N. Quality assessment of scientific outputs using the BWM. Scientometrics 2017, 112, 195-213. [CrossRef] [PubMed]

51. Durcikova, A.; Gray, P. How Knowledge Validation Processes Affect Knowledge Contribution. J. Manag. Inf. Syst. 2009, 25, 81-108. [CrossRef]

52. Kearns, G.S.; Sabherwal, R. Strategic Alignment between Business and Information Technology: A Knowledge-Based View of Behaviors, Outcome, and Consequences. J. Manag. Inf. Syst. 2006, 23, 129-162. [CrossRef]

53. Bharati, P.; Zhang, C.; Chaudhury, A. Social media assimilation in firms: Investigating the roles of absorptive capacity and institutional pressures. Inf. Syst. Front. 2013, 16, 257-272. [CrossRef]

54. Fichman, R.G. The Role of Aggregation in the Measurement of IT-Related Organizational Innovation. MIS Q. 2001, 25, 427-455. [CrossRef] 